\title{
Hubungan Body Dissatisfaction dan Perilaku Diet pada Mahasiswa Universitas Katolik Soegijapranata Semarang
}

\author{
Meiliana \\ Universitas Katolik Soegijapranata Semarang \\ meiliana@unika.ac.id \\ Vionna Valentina \\ Universitas Katolik Soegijapranata Semarang \\ vionnavalentina31@gmail.com \\ Christiana Retnaningsih \\ Universitas Katolik Soegijapranata Semarang \\ nik@unika.ac.id
}

\begin{abstract}
Body dissatisfaction reflects negative body image which may promote behavior changes in order to improve appearance. This study investigates the association between body dissatisfaction and dietary behavior of young adults. College students $(n=379)$ completed a survey on body dissatisfaction and dietary behavior in a cross-sectional research design and convenience non-probability sampling method. Information about nutritional status, reasons of dieting, dieting methods, dietary behavior scale, and body dissatisfaction scale were collected. Most respondents had normal weight status, poor dietary behavior, and body dissatisfaction. Obtaining attractive body shape was the most voted reason of dieting, while cutting eating frequency was the most frequent dieting method. There was a weak and contradicting ( $r=-$ 0.095) association between body dissatisfaction and dietary behavior which meant that body dissatisfaction was followed by poor dietary behavior.
\end{abstract}

Keywords: body dissatisfaction, dietary behavior, college student, body image

\begin{abstract}
Abstrak
Ketidakpuasan seseorang terhadap tubuhnya (body dissatisfaction) merupakan gambaran citra tubuh negatif yang dapat mendorong perilaku mengubah penampilan sesuai yang diharapkan. Penelitian ini bertujuan untuk mengetahui adanya hubungan body dissatisfaction dan perilaku diet pada mahasiswa Universitas Katolik Soegijapranata Semarang. Dengan rancangan penelitian cross-sectional dan metode pengambilan sampel convenience non-probability sampling, pengambilan data responden $(n=379)$ dilakukan menggunakan kuesioner untuk memperoleh informasi mengenai berat dan tinggi badan responden, alasan diet, metode diet, perilaku diet, dan skala body dissatisfaction. Sebanyak 58\% responden memiliki status gizi normal, $67 \%$ berperilaku diet tidak baik, dan $81 \%$ tidak puas terhadap bentuk tubuh. Memperoleh bentuk badan yang menarik adalah alasan $66 \%$ responden melakukan diet. Mengurangi frekuensi makan menjadi metode diet 52\% responden. Ada hubungan yang sangat lemah dan tidak searah ( $r=-0.095)$ antara body dissatisfaction dan perilaku diet pada responden yang berarti ketidakpuasan terhadap tubuh diikuti dengan perilaku diet yang tidak baik.
\end{abstract}

Kata kunci: ketidakpuasan terhadap tubuh, perilaku diet, mahasiswa, citra tubuh 


\section{PENDAHULUAN}

Perubahan komposisi dan bentuk tubuh pada masa transisi dari remaja menuju dewasa mempengaruhi citra tubuh yang merupakan persepsi dan perasaan secara sadar maupun tidak sadar mengenai ukuran dan bentuk tubuh (Khan et al., 2011; Yosephine, 2012). Perhatian lebih terhadap citra tubuh secara negatif dapat menimbulkan body dissatisfaction, yaitu ketidakpuasan seseorang akan bentuk dan ukuran tubuh mereka (Zainab, 2013).

Kesenjangan antara konsep tubuh ideal yang dimiliki seorang individu dengan kondisi tubuh yang sebenarnya akan menyebabkan perasaan tidak puas terhadap tubuh (Husna, 2013) dan mendorong keinginan untuk mengubah bentuk atau berat badan dengan melakukan "diet". Istilah "diet" yang sering digunakan oleh masyarakat merupakan usaha seorang individu dalam mengatur dan mengurangi asupan makanan untuk menurunkan dan mempertahankan berat badan (Chase, 2001) dengan menggunakan metode yang biasanya tidak sehat dan membahayakan tubuh (Hanum et al., 2014).

Untuk menurunkan berat badan, energi yang dikeluarkan tubuh harus lebih besar daripada asupan energi. Kondisi tersebut dapat dicapai melalui pengaturan jumlah, jenis, dan jadwal makan yang baik beserta peningkatan aktivitas fisik. Perilaku diet yang tidak baik akibat kurangnya pengetahuan dapat menjadi suatu kebiasaan dan meningkatkan risiko penyakit kronis di kemudian hari (Gamage \& Jayawardana, 2018).

Mahasiswa yang termasuk dalam kelompok usia remaja akhir dan dewasa awal umumnya mengalami penurunan ketergantungan terhadap orang tua sehingga teman memiliki peran penting dalam pengambilan keputusan. Mahasiswa yang tidak puas terhadap tubuhnya cenderung mengalami kesulitan dalam bersosialisasi dengan lingkungan sekitar dan mengambil keputusan secara mandiri sesuai dengan pengetahuan yang dimiliki (Yosphine, 2012), termasuk dalam memilih metode diet.

Wanita Asia (dari Jepang, Korea, dan Thailand) memiliki standar kurus yang lebih ketat dibandingkan etnis lainnya dan restriksi gender mungkin berpengaruh terhadap body dissatisfaction karena wanita Jepang memiliki cenderung memiliki body dissatisfaction yang lebih tinggi dibandingkan wanita Cina yang sama-sama memiliki berat badan yang 
relatif ringan. (Wardle, Haase, \& Steptoe, 2006; Yates, Edman, \& Aruguete, 2004).

Meskipun telah lama diteliti secara global, belum ada informasi akurat mengenai prevalensi body dissatisfaction di Indonesia. Pengumpulan data perlu dilakukan untuk meneliti body dissatisfaction beserta faktor risiko dan efek yang mungkin timbul pada masyarakat Indonesia. Penelitian ini bertujuan untuk mengetahui adanya hubungan body dissatisfaction dan perilaku diet pada mahasiswa Universitas Katolik Soegijapranata Semarang. Penelitian ini diharapkan dapat melengkapi riset dan informasi terkait body dissatisfaction dan perilaku diet di Indonesia.

\section{TELAAH LITERATUR DAN PENGEMBANGAN HIPOTESIS}

\section{Body Image}

Body image atau citra tubuh merupakan cara pandang, sikap, dan penilaian sesorang akan penampilan fisiknya yang terbentuk dalam pikiran orang itu sendiri baik secara sadar maupun tidak sadar. (Husna, 2013; Yosephine, 2012). Persepsi seseorang terhadap citra tubuh dapat bersifat negatif maupun poristif. Individu dengan citra tubuh positif biasanya ditandai dengan adanya penerimaan diri yang baik terkait penerimaan kelebihan dan kekurangan diri sendiri serta bersikap positif akan hal tersebut (Ridha, 2012). Sebaliknya, individu dengan citra tubuh negatif lebih berfokus pada kekurangan yang dimiliknya dan akan mengakibatkan adanya rasa ingin merubah penampilan diri dengan berbagai cara.

\section{Body Dissatisfaction}

Citra tubuh tidak ditentukan oleh bentuk dan ukuran tubuh sebenarnya tetapi oleh evaluasi subjektif seseorang mengenai tubuhnya dalam budaya tertentu. Body dissatisfaction sebagai bagian dari citra tubuh terjadi karena citra tubuh ditentukan secara sosial (Husna, 2013). Body dissatisfaction merupakan perbedaan antara persepsi individu tentang ukuran tubuh dengan ukuran tubuh yang sebenarnya. Persepsi adanya perbedaan antara ukuran tubuh yang sebenarnya dengan ukuran tubuh ideal menurut seorang individu menggambarkan ketidakpuasan terhadap ukuran dan bentuk tubuh (Ogden, 2002). Beberapa penilaian seseorang terhadap tubuhnya dapat dilihat dari beberapa hal seperti bentuk bagian tubuh tertentu (perut, payudara, pinggang, pinggul, pantat, paha, dan betis), berat badan, dan tinggi badan. 
Pengukuran body dissatisfaction dikonseptualisasikan ke dalam tiga perspektif (Ogden, 2002). Pada pespektif pertama, body dissatisfaction dipandang sebagai suatu estimasi mengenai ukuran tubuh dan persepsi bahwa tubuh lebih besar dari yang sebenarnya. Pada perspektif kedua, body dissatisfaction muncul saat individu memposisikan tubuh ideal yang ditentukan secara kultural dan menyadari bahwa ada perbedaan antara tubuhnya sendiri dibandingkan dengan tubuh ideal. Pada perspektif ketiga, respon negatif terhadap tubuh mengacu pada perasaan negatif dan kognisi mengenai tubuh individu.

\section{Perilaku Diet}

Perilaku diet merupakan bagian dari pola makan dan menggambarkan aspek perilaku makan yang meliputi kebiasaan makan, jumlah dan jenis makanan yang dikonsumsi, serta perasaan yang terbentuk ketika makan sebagai tindakan dari suatu pemikiran untuk mengkonsumsi makanan sesuai dengan keinginan individu (Furman, 2012; Sholeha, 2014).

Perilaku makan dapat dibedakan menjadi tiga aspek (Streint, 2013), yaitu:

\section{Emotional Eating: menunjukan} tindakan mengkonsumsi makanan secara berlebihan (tinggi kalori dan lemak) akibat respon emosi negatif seperti kecewa, putus asa, dan stres.

2. Restraint eating: biasanya dilakukan dengan membatasi asupan makan atau melawan dorongan makan secara sengaja dan berkelanjutan dengan tujuan untuk menurunkan berat badan.

3. Eksternal eating: melibatkan adanya rangsangan dari indra penglihatan, penciuman, dan perasa untuk makan terlepas dari adanya rasa lapar dan kenyang. Beberapa orang makan karena adanya respon yang kuat terhadap stimulus eksternal berupa penampilan atau rasa dibandingkan stimulus internal berupa rasa lapar.

Secara harfiah, diet berarti makanan. Akan tetapi, kata "diet" sering digunakan untuk menjelaskan usaha dan metode pengaturan makan, minum, dan aktivitas fisik untuk mendapatkan atau membentuk proporsi berat badan dan taraf kesehatan menjadi seimbang (Abdurrahman, 2014). Istilah diet sering diasosiasikan dengan usaha penurunan berat badan. Perilaku adalah suatu kegiatan, perbuatan, atau aktifitas yang dapat diamati dan dipelajari untuk mencapai tujuan tertentu karena adanya rangsangan dari lingkungan. (Abdurrahman, 2014; Andea, 2009). 
Dengan demikian, perilaku diet merupakan suatu kegiatan mengatur pola makan, minum, dan aktifitas fisik yang muncul karena adanya suatu rangsangan dari lingkungan sekitar dengan tujuan untuk menurunkan berat badan. Perilaku diet yang baik dilakukan secara tepat, sedangkan perilaku diet yang tidak baik dilakukan secara berlebihan. Beberapa contoh perilaku diet baik dan tidak baik dapat dilihat pada tabel 1 .

\section{Tabel 1. Perbandingan Perilaku Diet Baik dan Tidak Baik}

\begin{tabular}{|c|c|}
\hline Diet Baik & Diet Tidak Baik \\
\hline $\begin{array}{l}\text { Frekuensi makan sebanyak } 3 \text { kali sehari (jumlah makanan } \\
\text { tidak berlebihan dan tidak kekurangan) dan makan malam } \\
\text { pada waktu yang lebih awal setidaknya di bawah jam } 8 \\
\text { malam. }\end{array}$ & Menghilangkan kebiasaan sarapan dan makan malam. \\
\hline Mengganti nasi putih dengan nasi merah. & $\begin{array}{l}\text { Menghindari konsumsi nasi sebagai karbohidrat dengan } \\
\text { mengkonsumsi mie atau roti yang dianggap memiliki kalori } \\
\text { lebih rendah. }\end{array}$ \\
\hline Mengurangi cemilan yang mengandung lebih banyak kalori. & $\begin{array}{l}\text { Adanya anggapan ukuran makanan yang kecil dan ringan } \\
\text { memiliki kalori yang rendah. }\end{array}$ \\
\hline Menambah aktifitas fisik secara wajar. & Memuntahkan kembali makanan segera setelah dimakan. \\
\hline $\begin{array}{l}\text { Menjaga kesimbangan cairan dalam tubuh dengan minum air } \\
6-8 \text { gelas sehari. }\end{array}$ & $\begin{array}{l}\text { Berpuasa diluar niat ibadah dan hanya mengkonsumsi air } \\
\text { putih. }\end{array}$ \\
\hline $\begin{array}{l}\text { Konsumsi makanan mengikuti konsep piramida makanan } \\
\text { (Food Guide Pyramid). }\end{array}$ & $\begin{array}{l}\text { Hanya memakan buah dan sayur sebagai ganti makanan } \\
\text { berat. }\end{array}$ \\
\hline $\begin{array}{l}\text { Mengkonsumsi makanan rendah lemak dan mengkonsumsi } \\
\text { makanan rendah kalori. }\end{array}$ & $\begin{array}{l}\text { Penggunaan obat penurun berat badan, penahan nafsu makan } \\
\text { atau laxative. }\end{array}$ \\
\hline
\end{tabular}

\section{Indeks Massa Tubuh (IMT)}

Pengukuran berat badan tidak cukup menggambarkan status gizi dan bentuk tubuh seorang individu. Indeks pengukuran antropometri yang menggabungkan dengan pengukuran berat badan, tinggi badan, dan umur dapat diterjemahkan menjadi informasi status gizi (Yosephin, 2012). Status gizi individu juga dapat diukur menggunakan pengukuran Indeks Massa Tubuh (IMT) dengan perhitungan berat badan $(\mathrm{kg})$ dibagi dengan tinggi badan dikuadratkan $\left(\mathrm{m}^{2}\right)$ yang kemudian dibandingkan dengan klasifikasi WHO seperti tertera pada tabel 2.

\section{Hipotesis}
H1: Ada hubungan antara body dissatisfaction dan perilaku diet pada mahasiswa Universitas Katolik Soegijapranata Semarang 
Tabel 2. Kategori Indeks Massa Tubuh

(IMT) Orang Asia

\begin{tabular}{ll}
\hline Berat & IMT kg/(cm/100)2 \\
\hline Underweight & $<18,5$ \\
Normal & $18,5-24,99$ \\
Overweight & $\geq 25$ \\
Obese & $\geq 30$ \\
Obese I & $30-34,99$ \\
Obese II & $35-39,99$ \\
Obese III & $\geq 40$ \\
\hline Sumber: WHO, 2006 &
\end{tabular}

\section{METODE PENELITIAN}

\section{Desain Penelitian}

Penelitian ini dilakukan menggunakan rancangan penelitian crosssectional dan dilakukan di Universitas Katolik Soegijapranata yang beralamat di Jalan Pawiyatan Luhur IV/1 Bendan Duwur Semarang pada tanggal 19 September - 04 Oktober 2017. Berikut adalah diagram desain penelitian ini.

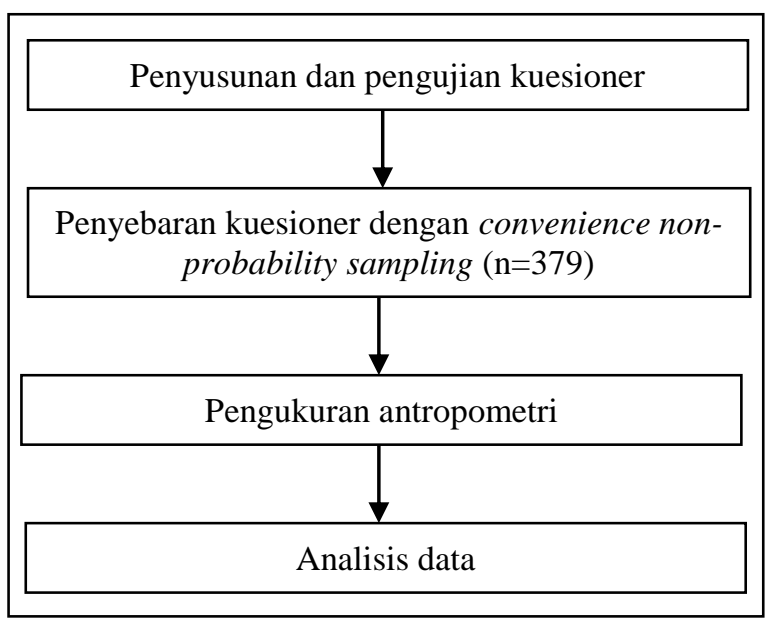

Gambar 1 Diagram Desain Penelitian

\section{Populasi dan Sampel}

Populasi dalam penelitian ini adalah 7084 mahasiswa Universitas Katolik Soegijapranata Semarang pada tahun ajaran 2017/2018. Rumus Slovin digunakan untuk menentukan jumlah sampel karena jumlah populasi yang akan diuji sudah diketahui (Dahlan, 2008). Dengan tingkat kesalahan 5\%, didapatkan jumlah sampel sebanyak 379 mahasiswa.

Rumus Slovin:

$\mathrm{n}=\mathrm{N} /\left(1+\mathrm{Nd}^{2}\right)$

$\mathrm{n}=7084 / 1+7084 \times 0,05^{2}$

$\mathrm{n}=378,621$

Keterangan:

$\mathrm{n}=$ jumlah sampel

$\mathrm{N}=$ jumlah populasi

$\mathrm{d}=$ tingkat kesalahan $5 \%=0.05$

Metode pengambilan sampel yang digunakan adalah convenience nonprobability sampling dengan memilih sampel sesuai kebutuhan sehingga setiap subyek yang kebetulan ditemukan dan dipandang cocok sebagai sumber data oleh peneliti dapat digunakan sebagai sampel (Abdurrahman, 2014). Berikut adalah kriteria sampel penelitian ini.

1. Mahasiswa Universitas Katolik Soegijapranata yang bersedia menjadi responden

2. Pernah atau sedang melakukan diet 
3. Adanya ketidakpuasan paling tidak 1 bagian tubuh (perut, paha, pinggul, pantat, atau lengan)

\section{Metode Pengumpulan Data}

\begin{abstract}
Pengambilan data dilakukan menggunakan kuesioner untuk memperoleh informasi mengenai berat dan tinggi badan responden, alasan diet, metode diet, perilaku diet, dan skala body dissatisfaction. Kuesioner yang sudah disusun diuji validitas dan reabilitas untuk mendapatkan pertanyaan-pertanyaan yang dapat digunakan dalam pengumpulan data. Responden diberi petunjuk pengisian kuesioner yang benar sebelum mulai mengisi kuesioner secara mandiri.
\end{abstract}

\section{Indeks Massa Tubuh (IMT)}

Berat badan dan tinggi badan diukur menggunakan timbangan jarum dan meteran. Status gizi dikategorikan menjadi kurus (IMT < 18.5), normal (IMT 18.5 - 24.99), dan gemuk (IMT $\geq 25$ ). Berikut prosedur pengukuran berat badan dan tinggi badan responden (Moore, 2009).

\section{Prosedur pengukuran berat badan}

1. Letakan alat ukur pada permukaan yang datar dan keras dan pastikan timbangan selalu pada titik keseimbangan nol
2. Pastikan responden tidak menggunakan pakaian yang tebal atau berat dan alas kaki

3. Posisikan badan berdiri tepat di tengah timbangan tanpa bantuan apapun, berdiri tegak menghadap ke depan dan rileks

4. Catat hasil pengukuran dalam satuan kilogram (kg).

\section{Prosedur pengukuran tinggi badan}

1. Carilah bidang vertikal untuk pengukuran dengan kondisi datar misalnya tembok

2. Pastikan responden tidak menggunakan alas kaki dan kondisi kepala bebas dari ikatan rambut atau asesoris rambut dan posisi tubuh tegak atau posisi siap, pandangan lurus ke depan, tangan berada di samping badan, serta betis, pantat, punggung, tumit dan kepala menempel pada bidang

3. Letakan penggaris di atas kepala subjek dengan lurus sehingga menempel pada bidang

4. Beri tanda titik dan meteran diturunkan dari tanda titik hingga dasar sebagai hasil tinggi badan dalam centimeter $(\mathrm{cm})$. 


\section{Perilaku Diet}

Perilaku diet diukur dengan skala likert yang disusun berdasarkan pengembangan dari penelitian oleh Yosephin (2012) serta sudah dirundingkan dan disetujui oleh tim peneliti. Kuisioner terdiri dari 17 pernyataan positif atau favourable dan 9 pernyataan negatif atau unfavourable. Skala likert yang digunakan memiliki 6 poin kontinuum dari tidak pernah hingga selalu. Jawaban baik (selalu, sangat sering, dan sering pada pernyataan positif beserta kadang-kadang, jarang, dan tidak pernah pada pernyataan negatif) memiliki skor 1, sedangkan jawaban tidak baik memiliki skor 0. Hasil skoring dibagi menjadi 2 klasifikasi yaitu perilaku diet baik (total skor minimal 14) dan tidak baik (total skor kurang dari 14).

\section{Body Dissatisfaction}

Body dissatisfaction diukur dengan skala adaptasi dari Body Shape Quisionnaire (BSQ-34) hasil dari perkembangan oleh Cooper, Taylor, Fairburn (1987 dalam Hanum 2014). Kuisioner ini terdiri dari 34 pertanyaan terkait dengan ketidakpuasan terhadap tubuh seperti perut, pinggul, pantat, paha, betis dan lengan. Tiap pertanyaan memiliki skor atau skala likert dari 1 sampai 6 dengan tidak pernah $=1$ dan selalu $=6$. Hasil skoring dibagi menjadi 2 klasifikasi yaitu merasa puas (total skor kurang dari 80) dan tidak puas (total skor minimal 80) dengan tubuh masingmasing.

\section{Metode Analisis Data}

Uji validitas dan reabilitas digunakan untuk menganalisis kuesioner perilaku diet yang disusun oleh tim peneliti. Data responden yang didapatkan dari pengisian kuesioner diolah dan dianalisis menggunakan program Microsoft Excel dan program aplikasi statistik SPSS. Uji Kendall Tau-b digunakan untuk mengetahui hubungan antara dua variable atau lebih yang merupakan data ordinal dengan menggunakan derajat kepercayaan 95\% (Dahlan, 2008).

\section{HASIL DAN PEMBAHASAN}

\section{Status Gizi, Perilaku Diet, dan Body}

\section{Dissatisfaction}

Hasil kuesioner (Tabel 3) menunjukkan bahwa status gizi responden laki-laki lebih banyak tergolong dalam kategori gemuk (62,50\%), sedangkan untuk responden perempuan lebih banyak tergolong dalam kategori normal $(70.12 \%)$. Perilaku diet responden lakilaki dan perempuan memiliki persentase terbesar pada kategori perilaku diet tidak baik yaitu $64.06 \%$ dan $67.73 \%$. 
Responden yang digunakan pada penelitian ini adalah mereka yang merasa tidak puas paling tidak pada satu bagian tubuh. Setelah diukur secara lebih akurat menggunakan skala adaptasi dari BSQ-34, mayoritas responden tidak puas terhadap tubuh mereka dengan persentase body dissatisfaction responden laki-laki dan perempuan sebesar $76.56 \%$ dan $82.87 \%$.

Tabel 3. Status Gizi, Perilaku Diet, dan Skala Body Dissatisfaction Responden

\begin{tabular}{|c|c|c|c|c|c|}
\hline \multirow[t]{2}{*}{ Variabel } & \multicolumn{4}{|c|}{ Jumlah Responden $(n=379)$} & \multirow{2}{*}{$\begin{array}{c}\text { Total } \\
\text { Persentase } \\
(\%)\end{array}$} \\
\hline & $\begin{array}{c}\text { Laki-laki } \\
(n=128)\end{array}$ & $\begin{array}{c}\text { Persentase } \\
(\%)\end{array}$ & $\begin{array}{c}\text { Perempuan } \\
(n=251)\end{array}$ & $\begin{array}{c}\text { Persentase } \\
(\%)\end{array}$ & \\
\hline \multicolumn{6}{|l|}{ Status Gizi: } \\
\hline Kurus & 4 & 3.13 & 22 & 8.76 & 6.86 \\
\hline Normal & 44 & 34.38 & 176 & 70.12 & 58.05 \\
\hline Gemuk & 80 & 62.50 & 53 & 21.12 & 35.09 \\
\hline \multicolumn{6}{|l|}{ Perilaku Diet: } \\
\hline Baik & 46 & 35.94 & 81 & 32.27 & 33.51 \\
\hline Tidak Baik & 82 & 64.06 & 170 & 67.73 & 66.49 \\
\hline \multicolumn{6}{|l|}{ Body Dissatisfaction: } \\
\hline Puas & 30 & 23.44 & 43 & 17.13 & 19.26 \\
\hline Tidak Puas & 98 & 76.56 & 208 & 82.87 & 80.74 \\
\hline
\end{tabular}

Hasil tersebut menunjukkan bahwa mayoritas responden memiliki status gizi yang normal (58.05\%), namun sebagian besar merasa tidak puas dengan bentuk tubuhnya (80.74\%), sehingga mereka memiliki perilaku diet yang cenderung ke arah tidak baik (66.49\%).

Mahasiswi yang melakukan diet cenderung mengalami gangguan makan dan memiliki perilaku diet yang tidak baik dengan cara berpuasa, menggunakan obat pencahar berlebihan, dan membiarkan tubuh kelaparan walaupun memiliki status gizi normal (Erdianto, 2009; Husna, 2013 ; Rifsyina, 2015). Ketidakpuasan terhadap tubuh sekalipun status gizi normal dapat disebabkan adanya standar bentuk tubuh ideal tertentu dan keinginan untuk menyamakan bentuk tubuh dengan orang lain.

\section{Alasan Diet dan Metode Diet \\ Responden dapat memilih lebih dari satu jawaban saat mengisi pertanyaan kueioner mengenai alasan diet dan metode diet yang pernah atau sedang dilakukan. Hasil dapat dilihat pada tabel 4.}


Tabel 4. Alasan Diet dan Metode Diet Pada Mahasiswa Universitas Katolik Soegijapranata

\begin{tabular}{lll}
\hline Variabel & Jumlah $(\mathbf{n = 3 7 9 )}$ & Persentase (\%) \\
\hline Alasan Diet: & & \\
Agar lebih sehat & 185 & 48.81 \\
Mendapatkan bentuk badan yang menarik & 251 & 66.23 \\
Mencegah berat badan naik & 125 & 32.98 \\
Metode Diet: & & \\
Mengurangi karbohidrat & 196 & 51.72 \\
Mengurangi lemak & 147 & 38.79 \\
Mengurangi gula & 135 & 35.62 \\
Mengurangi frekuensi makan & 199 & 52.51 \\
Menggunakan obat pelangsing & 31 & 8.18 \\
Olahraga lebih berat & 163 & 43.01 \\
\hline
\end{tabular}

Dari 379 responden sebanyak 185 mahasiswa (48.81\%) melakukan diet agar memperoleh badan yang sehat; sebanyak 251 mahasiswa (66.23\%) menginginkan bentuk badan yang menarik; dan 125 mahasiswa $(32.98 \%)$ mencegah adanya kenaikan berat badan. Sebagian besar mahasiswa melakukan diet dengan mengurangi frekuensi makan (52.51\%) dan mengurangi konsumsi karbohidrat $(51.72 \%)$ untuk mendapatkan badan yang menarik, sedangkan penggunakan obat pelangsing adalah metode yang paling sedikit digunakan oleh responden $(8.18 \%)$.

Korelasi antara Status Gizi, Perilaku Diet, dan Body Dissatisfaction

Hasil uji korelasi Kendall Tau-b pada IMT terhadap body dissatisfaction dan perilaku diet terhadap body dissatisfaction dapat dilihat pada Tabel 5.

Tabel 5. Hasil Uji Korelasi Kendall Tau-b

\begin{tabular}{llr}
\hline Variabel & & Body Dissatisfaction \\
\hline Status Gizi & Koefisien korelasi (r) & 0.140 \\
& Signifikansi (p value) & 0.000 \\
& $\mathrm{~N}$ & 379 \\
\multirow{2}{*}{ Perilaku Diet } & Koefisien korelasi (r) & \\
& Signifikansi (p value) & 0.095 \\
& $\mathrm{~N}$ & 0.000 \\
& & 379 \\
\hline
\end{tabular}

Ada korelasi yang signifikan tetapi sangat lemah antara status gizi dan body dissatisfaction $(\mathrm{p}=0.000, \mathrm{r}=0.140)$ dan perilaku diet dan body dissatisfaction $(\mathrm{p}=$ $0.000, \mathrm{r}=-0.095)$. Nilai koefisien korelasi yang bernilai positif pada uji korelasi 
status gizi dengan body dissatisfaction menunjukan hubungan yang searah, yang berarti semakin besar nilai IMT, semakin besar rasa tidak puas terhadap tubuh.

Media merupakan salah satu faktor pembentuk citra tubuh seorang individu. Model iklan dengan bentuk tubuh tertentu yang dianggap ideal secara sosial menjadi standar dan tolak ukur secara sadar maupun tidak sadar.

Sementara itu, nilai koefisien korelasi yang bernilai negatif pada uji korelasi perilaku diet dengan body dissatisfaction menunjukan hubungan antara body dissatisfaction terhadap status gizi yang tidak searah. Rasa tidak puas terhadap tubuh yang semakin besar diikuti dengan perilaku diet yang semakin tidak baik.

Perilaku diet yang tidak baik dapat terjadi karena tidak adanya arahan atau petunjuk dokter atau ahli gizi selama melakukan diet (Husna, 2013). Sering didapati bahwa diet yang dijalankan tidak sesuai dengan aturan kesehatan dan hanya mengutamakan cara mendapatkan badan yang ideal cepat dan mudah dengan mengesampingkan resikonya.

Hasil penelitian ini menunjukkan bahwa body dissatisfaction tidak banyak mempengaruhi perilaku diet mahasiswa karena walaupun body dissatisfaction rendah responden tetap melakukan diet. Hal ini didukung dengan hasil penelitian
Dion (2008) pada 120 responden yang membuktikan bahwa sekitar $60 \%$ responden merasa tidak puas terhadap bentuk tubuh mereka dan melakukan diet untuk mendapatkan bentuk badan yang ideal, sedangkan sisanya sekitar $40 \%$ merasa puas terhadap tubuhnya tetapi tetap melakukan diet untuk mempertahankan berat badan.

\section{SIMPULAN}

Sebanyak $58 \%$ responden memiliki status gizi normal, $67 \%$ berperilaku diet tidak baik, dan $81 \%$ tidak puas terhadap bentuk tubuh. Memperoleh bentuk badan yang menarik adalah alasan $66 \%$ responden melakukan diet. Mengurangi frekuensi makan menjadi metode diet $52 \%$ responden. Hubungan antara body dissatisfaction dan status gizi sangat lemah dan searah $(r=0.140)$ yang menunjukan peningkatan nilai indeks masa tubuh diikuti dengan peningkatan rasa tidak puas terhadap tubuh. Ada hubungan yang sangat lemah dan tidak searah $(\mathrm{r}=-0.095)$ antara body dissatisfaction dan perilaku diet pada responden yang berarti ketidakpuasan terhadap tubuh diikuti dengan perilaku diet yang tidak baik.

Penelitian di masa mendatang sebaiknya dilakukan pada mahasiswa 
yang sedang melakukan diet tanpa melibatkan mahasiswa yang pernah diet tapi tidak melakukannya lagi. Selain itu, penelitian yang melihat perbedaan karakteristik antara mahasiswa yang merupakan atlet dan bukan dapat melengkapi riset dan informasi terkait body dissatisfaction dan perilaku diet di Indonesia.

\section{DAFTAR PUSTAKA}

Gamage, A. U., \& Jayawardana, P. L. (2018). Knowledge of noncommunicable diseases and practices related to healthy lifestyles among adolescents, in state schools of a selected educational division in Sri Lanka. BMC Public Health, 18, 64. http://doi.org/10.1186/s12889-0174622-z

Abdurrahman, Fadlullah. 2014. Faktorfaktor Pendorong Perilaku Diet Tidak Sehat Pada Wanita Usia Dewasa Awal Studi Kasus pada Mahasiswi Universitas Mulawarman. eJuornal Psikologi. Vol 2(2):163170. http://ejournal.psikologi.fisipunmul.ac.id/site/wpcontent/uploads/2014/08/jurnal\%20fi x\%20(08-29-14-12-24-35).pdf

Adlard, L. 2006. The Relationship Between Body Dissatisfaction of Mothers and Body Dissatisfaction of Their Adolescent Daughters. Essay. Faculty of Humanities. The University of Pretoria. https://repository.up.ac.za/bitstream/ handle/2263/29564/dissertation.pdf; $s$ equence $=1$
Andea, Raisa. 2009. Hubungan Antara Body Image dan Perilaku Diet Pada Remaja. Skripsi. Fakultas Psikologi.Universitas Sumatera Utara. http://repository.usu.ac.id/bitstream/h andle/123456789/14525/10E00103.p df? sequence $=1$

Bearman, S.K, Martinez, E., \& Stice, E. 2006. The skinny on body dissatisfaction: A longitudinal study of adolescent girls and boys. Journal of Youth Adolescent. Vol 35(2):217229.

https://www.ncbi.nlm.nih.gov/pmc/ar ticles/PMC1540456/pdf/nihms7756.pdf

Chase, M.E. 2001. Identitiy Development and Body Image Dissatisfaction in College Female. Research. The University of Wisconsin: Stout. http://www2.uwstout.edu/content/lib/ thesis/2001/2001chasem.pdf

Dahlan, Sopiyudin. 2008. Statistik untuk Kedokteran dan Kesehatan. Jakarta: Salemba Medika. https://books.google.co.id/books?id= $\mathrm{Abh} 5 \mathrm{OaO} 3 q \mathrm{qMC} \&$ printsec $=$ frontcov er\&hl=id\&source=gbs_ge_summary $\_\mathrm{r} \& \mathrm{cad}=0 \# \mathrm{v}=$ onepage $\& \mathrm{q} \& \mathrm{f}=$ false

Erdianto, Sigit Dwi. 2009. Hubungan Antara Faktor Individu Dan Faktor Lingkungan Dengan Kecenderungan Penyimpangan Perilaku Makan Pada Mahasiswi Jurusan Administrasi Perkantoran Dan Sekretaris FISIP UI. Skripsi. Fakultas Kesehatan Masyarakat. Universitas Indonesia: Depok. http://lib.ui.ac.id/file?file=digital/126 740-S-5685-Hubungan\%20antaraHA.pdf

Furman, Ellen Frances. 2012. The Theory of Compromised Eating Behavior. Dissertations and Thesi. University of Massachusetts: Amherst. 
http://scholarworks.umass.edu/cgi/vi ewcontent.cgi?article $=1510 \&$ context =open_access_dissertations 28

Hanum, R., Entin Nurhayati dan Siti Nur Riani. 2014. Pengaruh Body Dissatisfaction dan Self-Esteem Dengan Perilaku Diet Mahasiswi Universitas " $X$ " Serta Tinjuauan Dalam Islam. Jurnal Psikogenesis. Vol. 2(2):180-190. http://academicjournal.yarsi.ac.id/ind ex.php/Jurnal-Online-

Psikogenesis/article/view/51

Husna, Nur L. 2013. Hubungan antara Body Image dengan Perilaku Diet. Skripsi. Fakultas Ilmu Pendidikan Jurusan Psikologi. Universitas Negri: Semarang. http://lib.unnes.ac.id/18410/1/155040 6005.pdf

Khan, R. A. G., F. A. Khan, et al. 2011. Impact of Training and Development on Organizational Performance. Global Journal of Management and Business Research. Vol. 11(7):62-68. https://globaljournals.org/GJMBR_V olume11/8-Impact-of-Training-andDevelopment-on-OrganizationalPerformance.pdf

Kurnianingsih, Yulianti. 2009. Hubungan faktor individu dan lingkungan terhadap diet penurunan berat badan pada remaja putri di 4 SMA terpilih di Depok. Skripsi. Fakultas Kesehatan Masyarakat. Universitas Indonesia: Depok. http://lib.ui.ac.id/file?file=digital/125 356-S-5714-Hubungan\%20faktorHA.pdf

Merdeka. 2015. Lima Jenis Diet ini Terkenal Mampu Turunkan Berat Badan dengan Cepat. Diambil dari: www.merdeka.com/sehat/5-jenisdiet-ini-terkenal-mampu-turunkanberat-badan-dengan-cepat/cleaneating.html (28 November 2017).
Moore, J Barbara. 2009. Assesment of Children How to Use Repeated Measures of Body Mass Index (BMI) To Assess and Prevent Obesity in Children. P11-12. Diambil dari: http://healthinfo.montana.edu/healthwellness/Assessment $\% 20$ of $\% 20$ Chil dren $\% 20 \mathrm{Feb} \% 202010 \% 20 \mathrm{MTNAP}$ A.pdf (24 Oktober 2017).

Navia, B., et al. 2003. Influence of The Desire to Lose Weight on Foods Habits, and Knowledge of The Characteristic of Balanced Diet, In A Group of Madrid University Student. Europan Journal of Chlinical Nutrition. Vol. 57, S90-S93. https://www.ncbi.nlm.nih.gov/pubme d/12947464

Neumark-Sztainer D, Fulkerson JA, Hannan PJ, Story M. 2008. Family meal frequency and weight status adolescent: cross-sectional and 5 year longitudinal associations. Obesity a Research Journal. Vol. 16(11):2529-2534.

http://onlinelibrary.wiley.com/doi/10. 1038/oby.2008.388/full 29

Putri, R. P. 2008. Perilaku Diet Pada Remaja Putri Ditunjau Dari Harga Diri. Skripsi. Fakultas Psikologi. Universitas Katolik Soegijapranata: Semarang. P1. http://repository.unika.ac.id/5566/1/0 $3.40 .0235 \% 20$ Ratih\%20Permata\%20 Putri\%20COVER.pdf

Ridha, M. 2012. Hubungan Antara Body Image Dengan Penerimaan Diri Pada Mahasiswa Aceh Di Yogyakarta. Jurnal Empathy Vol. 1(1):111-121. https://www.academia.edu/5181791/ HUBUNGAN_ANTARA_BODY_I MAGE_DENGAN_PENERIMAAN _DIRI_PADA_MAHASISWA_ACE H_DI_YOGYAKARTA 
Rifsyina, Nida N. 2015. Pengetahuan, Persepsi, dan Penerapan Diet Penurunan Berat Badan pada Mahasiswa Gizi Putra. J. Gizi Pangan. Vol 10(2):109-116. http://journal.ipb.ac.id/index.php/jgiz ipangan/article/view/10888

Sholeha, Lia. 2014. Hubungan Perilaku Makan Terhadap Indeks Massa Tubuh pada Remaja di SMP YMJ Ciputat. Skripsi. Fakultas Kedokteran dan Ilmu Kesehatan. Universitas Islam Negri Syarif Hidayatullah: Jakarta. http://repository.uinjkt.ac.id/dspace/b itstream/123456789/25583/1/LIA\%2 OSHOLEHA-FKIK.pdf

Streint, Tatjana., Cebolla, A., \& Barrada, Juan R. 2013. Internal Structure and Measurement Invariance of The $D E B Q . \quad$ Diambil dari: www.researchgate.net/publication/29 6846760_Internal_Structure_and_Me asurement_Invariance_of_the_Dutch _Eating_Behavior_Questionnaire_D EBQ_in_a_Nearly_Representative_D utch_Community_Sample Oktober 2017).

Tumiwa-Bachrens, Inge. 2016. Eating Clean. Jakarta: Kawan Pustaka.

Wardle, J., Haase, A. M., \& Steptoe, A. (2006). Body image and weight control in young adults: International comparisons in university students from 22 countries. International
Journal of Obesity, 30, 644-651. doi:10.1038/sj.ijo.0803050

World Health Organization (WHO). 2006. Global Database on Body Mass Index. Diambil dari: www.assessmentpsychology.com/icb mi.htm (24 Oktober 2017).

Yosephine. 2012. Hubungan Citra Tubuh terhadap Perilaku Diet Mahasiswi.Skripsi. Fakultas Ilmu Keperawatan. Universitas Indonesia: Depok.

http://lib.ui.ac.id/file?file=digital/203 08604-S42556-

Hubungan\%20citra.pdf

Yulia, R.N, et al. 2014. Diet Remaja (Psikologi dan Kespro Remaja). Jakarta: PT. Mustika Cendekia Negeri.

Yates, A., Edman, J., \& Aruguete, M. (2004). Ethnic differences in BMI and body/self-dissatisfaction among Whites, Asian subgroups, Pacific Islanders, and African Americans. Journal of Adolescent Health, 34, 300-307.

Zainab, Naily. 2013. Peranan Self-Esteem dan Body Dissatisfaction Dalam Memprediksi Kecenderungan Eating Disorders Pada Penari Balet. Thesis. Fakultas Psikologi. Universitas Bina Nusantara: Jakarta. http://thesis.binus.ac.id/doc/Lainlain/2012-2-00525PS\%20WorkingPaper001.pdf 